\title{
ANALISIS PERLAKUAN DAN PELAPORAN AKUNTANSI BARANG MILIK NEGARA PADA KANTOR WILLAYAH KEMENTERIAN AGAMA PROVINSI SULAWESI UTARA
}

\author{
Muamar Albar ${ }^{1}$, Jenny Morasa ${ }^{2}$, Stanly Kho Walandouw ${ }^{3}$ \\ 1,Jurusan Akuntansi, Fakultas Ekonomi dan Bisnis Universitas Sam Ratulangi, Jl. Kampus Bahu, Manado, \\ 95115, Indonesia \\ E-mail : Muamaramar93@gmail.com
}

\begin{abstract}
State-Owned Country (BMN/D) is an important element in the government's performance especially in providing servant to the public, central or local government, which must manage the BMN/D in order to be useful for the government and society. BMN/D's Management is a process in manage pre-existing wealth or obtained from APBN/D expenses or other legal result that can be used in government and society's activities. The classification BMN consists of, inventory, land, equipment and machine, buildings and construction, roads, irrigation and networks, construction in progress, and other fixed assets. The government has implemented procurement of good's which is financed from (APBN). This study is aims to determine the accounting treatment and reporting for state-owned country (BMN) at the Regional representative Office of the Ministry of Religious Affairs in North Sulawesi Province. The research used descriptive method which aims that each data collected is analyzed, then drawn a conclusion and this type of research is qualitative descriptive. The results of this study is accounting treatment of state-owned country at the Regional representative Office of the Ministry of Religious Affairs in North Sulawesi Province has been based on accrual and the office's reporting already in accordance with SAP (Government Accounting Standard) technical bulletin number 15.
\end{abstract}

Keywords: Treatment, Accounting Reporting, BMN

\section{PENDAHULUAN}

Pasal 1 angka 10 dan angka 11 Undang-Undang nomor 1 tahun 2004 tentang perbendaharaan negara, dimana ruang lingkup barang milik negara selain yang berasal dari pembelian atau perolehan atas beban anggaran pendapatan dan belanja negara juga berasal dari perolehan lainnya yang sah. Barang milik negara yang bersumber dari perolehan lainya yang secara sah harus diperjelas lingkupnya yang meliputi barang yang diperoleh dari hibah/sumbangan/sejenisnya, diperoleh sebagai pelaksanaan perjanjian/kontrak, diperoleh berdasarkan ketentuan Undang-Undang dan diperoleh berdasarkan putusan pengadilan yang telah memperoleh ketentuan hukum tetap. BMN/D adalah sumber daya ekonomi yang dikuasai dan/atau dimiliki oleh pemerintah pusat atau daerah maka pengelolaan BMN/D tersebut harus dilakukan secara baik dan benar (Yusuf:2010). Pengelolaan dilakukan secara baik dan benar bermakna pengelolaan BMN/D harus taat asas (Chabib Sholeh dan Heru Rochamjah:2010). Adapun asas-asas dalam pengelolaan BMN/D meliputi: asas fungsional, asas kepastian hukum, asas transparansi, asas keterbukaan, asas efesiensi, asas akuntabilitas dan asas kepastian nilai. Klasifikasi barang milik negara terdiri dari, persediaan, tanah, peralatan dan mesin, gedung dan bangunan, jalan, irigasi dan jaringan, konstruksi dalam pengerjaan, aset tetap lainnya. Setiap tahun pemerintah melakukan pengadaan barang yang dibiayai dari Anggaran Pendapatan dan Belanja Negara (APBN).

Kantor Wilayah Kementerian Agama Provinsi Sulawesi Utara merupakan salah satu instansi pemerintah yang menjadi kuasa pengguna Barang Milik Negara (BMN). Barang Milik Negara (BMN) yang ada pada Kantor Wilayah Kementerian Agama terdiri dari 
persediaan, peralatan dan mesin serta gedung dan bangunan. Adapun perlakuan akuntansi terhadap Barang Milik Negara (BMN) pada Kantor Wilayah Kementerian Agama Provinsi Sulawesi Utara mengimplementasikan perlakuan akuntansi berbasis akrual yang mengakui pendapatan, belanja, dan pembiayaan dalam pelaksanaan anggaran berdasarkan basis yang ditetapkan dalam APBN/APBD.

Tata cara pelaksanaan penggunaan, pemanfaatan, penghapusan dan pemindahtanganan Barang Milik Negara, hal ini merupakan acuan bagi pejabat pengguna/kuasa pengguna Barang Milik Negara dalam melaksanakan tugas dan fungsinya secara efektif dan efisien yang dimana diatur dalam Peraturan Menteri Keuangan Nomor 96/PMK.06/2007 Peraturan Menteri Keuangan Nomor 96/PMK.06/2007 Sesuai Standar Akuntansi Pemerintahan Buletin Teknis nomor 15 tentang asset tetap berbasis akrual, dimana mengatur perlakuan akuntansi untuk aset tetap yang meliputi pengakuan, penentuan nilai tercatat, serta penentuan dan perlakuan akuntansi atas penilaian kembali dan penurunan nilai tercatat (carrying value) aset tetap serta banyaknya kasus mengenai keterlambatan pelaporan Barang Milik Negara pada Kantor Pelayanan Kekayaan Negara dan Lelang (KPKNL).

\section{TINJAUAN PUSTAKA}

\subsection{Akuntansi Pemerintah}

Dalam teori Bastian (2010:6) menyatakan akuntansi pemerintah yaitu mekanisme teknik dan analisis akuntansi yang diterapkan pada pengelolaan dana masyarakat di lembagalembaga tinggi negara dan departemen-departemen di bawahnya, pemerintah daerah, Badan Usaha Milik Negara, Badan Usaha Milik Daerah, Lembaga Sosial Masyarak dan yayasan sosial pada proyek-proyek kerjasama sektor publik dan swasta.

\subsubsection{Standar Akuntansi Pemerintahan}

Untuk menyusun dan menyajikan laporan keuangan pemerintah, yang terdiri atas Laporan Keuangan Pemerintah Pusat (LKPP) dan Laporan Keuangan Pemerintah Daerah (LKPD), dalam rangka transparansi dan akuntabilitas penyelenggaraan akuntansi pemerintahan, serta peningkatan kualitas LKPP dan LKPD" harus berdasarkan auan akuntansi yang diterapkan sebagaimana yang dijelaskan dalam teori Tanjung (2012) dan Agustiawan (2013)

\subsubsection{Standar Akuntansi Pemerintahan Berbasis Akrual}

Sejak tahun 2015, Indonesia sudah mengimplementasikan Standar Akuntansi Pemerintahan Berbasis Akrual. Peraturan Pemerintah Nomor 71 Tahun 2010 Pasal 1 ayat (8) menyatakan bahwa standar akuntansi pemerintahan berbasis akrual dalam pelaporan finansial yaitu mengakui pendapatan, beban, aset, utang dan ekuitas dan dalam pelaksanaan anggaran harus mengakui pendapatan, belanja dan pembiayaan berdasarkan basis yang ditetapkan dalam APBN/APBD.

\subsection{Barang Milik Negara}

Berdasarkan Peraturan Pemerintah Nomor 27 Tahun 2014 tentang Pengelolaan Barang Milik Negara/Daerah yang dimaksud dengan Barang Milik Negara adalah semua barang yang dibeli atau diperoleh atas beban APBN atau yang berasal dari perolehan lainnya yang sah.

\subsubsection{Asas-Asas Dalam Pengelolaan Barang Milik Negara}

1. Asas fungsional

Asas fungsional yaitu pengambilan keputusan dan pemecahan masalah di bidang pengelolaan BMN/D sesuai fungsi, wewenang dan tanggung jawab masing-masing pejabat yang mengelola BMN/D.

2. Asas kepastian hukum

Asas kepastian hukum yaitu mengelola BMN/D harus dilaksanakan berdasarkan hukum dan peraturan perundang-undangan. 
3. Asas transparansi atau asas keterbukaan

Asas transparansi atau asas keterbukaan yaitu harus dilakukan secara transparan terhadap hak masyarakat dalam memperoleh informasi yang benar dalam penyelenggaraan penggelolaan BMN/D.

4. Asas efesiensi

Asas efisiensi yaitu harus diarahkan sesuai dengan pengelolaan BMN/D agar digunakan sesuai batas standar kebutuhan yang diperlukan dalam rangka menunjang penyelenggaraan tugas pokok dan fungsi pemerintahan secara optimal.

5. Asas akuntabilitas

Asas akuntabilitas yaitu setiap kegiatan pengelolaan BMN/D harus dapat dipertanggungjawabkan kepada rakyat.

6. Asas kepastian nilai.

Asas kepastian nilai yaitu optimalisasi pemanfaatan dan pemindahtanganan BMN/D serta penyusunan neraca pemerintah pusat/daerah mengenai ketetapan jumlah dan nilai.

\section{3. $\quad$ Asset Tetap}

Aset tetap adalah barang berumur lebih dari satu tahun, untuk itu data pada pengelolaan atau pejabat yang mengurus aset/barang tersebut perlu dicatat secara lengkap termasuk informasi tentang nilai. Sumber awal data aset/barang adalah pada pejabat/panitia pengadaan dan pimpinan pelaksanaan teknis kegiatan untuk aset/barang yang berasal dari APBN, sedangkan sumber awal aset/ barang yang berasal dari hibah dan penyerahan dari pihak ketiga adalah tim atau pejabat yang ditunjuk untuk menerima aset/barang tersebut.

\subsubsection{Akuntansi Asset Tetap}

Klasifikasian aset tetap berdasarkan kesamaan dalam sifat atau fungsinya dalam aktivitas operasi entitas sebagaimana yang dinyatakan dalam PSAP BA 07 paragraf 7. Klasifikasi aset tetap adalah:

1.Golongan Tanah

2.Golongan Peralatan dan Mesin

3.Golongan Gedung dan Bangunan

4.Golongan Jalan, Irigasi dan Jaringan

5.Golongan Konstruksi Dalam Pengerjaan

6.Golongan Aset Tetap Lainnya

\subsection{Pelaporan}

Suatu kegiatan yang dilakukan bawahan untuk menyampaikan hal-hal yang berhubungan dengan hasil pekerjaan yang telah dilakukan selama satu periode tertentu dan catatan yang memberikan informasi tentang kegiatan tertentu dan hasilnya disampaikan ke pihak yang berwenang atau berkaitan dengan kegiatan tertentu (Siagian, 2011).

\subsubsection{Ketentuan Terkait Akuntansi Pelaporan Barang Milik Negara}

Tujuan pelaporan adalah menyampaikan/ mendapatkan data dan informasi BMN hasil pembukuan dan inventarisasi yang dilakukan oleh pelaksana penatausahaan pada Saldo Awal Saldo akhir periode sebelumnya Koreksi saldo Perolehan BMN Hibah Pembelian Penyelesaian Pembangunan Pelaksanaan dari perjanjian/kontrak Pembatalan penghapusan Rampasan Reklasifikasi Masuk Transfer Masuk Perubahan BMN Pengurangan Pengembangan Perubahan Kondisi Revaluasi Penghapusan BMN Penghapusan Transfer keluar Hibah Reklasifikasi Keluar 5 pengguna barang dan pengelola barang yang akurat sebagai bahan pengambilan kebijakan mengenai pengelolaan BMN dan sebagai bahan penyusunan Neraca Pemerintah Pusat.

\subsection{Penelitian Terdahulu}

Penelitian terdahulu yang penulis jadikan sebagai bahan pertimbangan dalam melakukan penelitian di Kantor Wilayah Kementerian Agama Provinsi Sulawesi Utara. Penelitian yang dilakukan oleh Leli tahun 2015, tentang analisis perlakuan akuntansi aset 
tetap berdasarkan PSAP no 07 menyatakan bahwa perlakuan akuntansi aset tetap pada dinas pertanian dan ketahanan pangan Provinsi Jawa Timur yang meliputi pengakuan, pengukuran, penghentian dan pelepasan serta pengungkapan pada periode tahun 2011-2014 dapat disimpulkan sedah sesuai dengan ketentuan dalam PSAP no 07, namun perlakuan akuntansi untuk penyusutan aset tetap baru dilakukan pada periode tahun 2014.

\section{METODE PENELITIAN}

\subsection{Jenis Penelitian}

Penelitian yang dilakukan merupakan Penelitian Deskriptif. Sukmadinata (2013) menyatakan bahwa penelitian deskriptif adalah suatu penelitian yang ditujukan untuk mendeskripsikan dan menggambarkan fenomena-fenomena yang ada baik fenomena yang bersifat alamiah atau rekayasa manusia). Secara sederhana Penelitian Deskriptif adalah Penelitian yang menjelaskan setiap data yang diperoleh, fenomena yang terjadi dan hasil penelitian di lapangan yang ditemukan, dalam bentuk kata-kata yang menceritakan, mengemukakan dan menggambarkan situasi tersebut yang memiliki makna sesuai dengan hasil penelitian yang dilakukan.

Jenis data yang digunakan dalam penelitian ini meliputi data kualitatif dan data kuantitatif. Data kualitatif berupa bahan keterangan dalam bentuk uraian kata-kata dan tidak diukur dalam skala numerik berupa data tentang peraturan pemerintah mengenai standar akuntansi pemerintahan, tentang perlakuan dan pelaporan akuntansi barang milik negara, sedangkan data kuantitatif berupa Laporan Keuangan Kantor Wilayah Kementerian Agama Provinsi Sulawesi Utara. Secara sederhana Penelitian Deskriptif adalah Penelitian yang menjelaskan setiap data yang diperoleh, fenomena yang terjadi dan hasil penelitian di lapangan yang ditemukan, dalam bentuk kata-kata yang menceritakan, mengemukakan dan menggambarkan situasi tersebut yang memiliki makna sesuai dengan hasil penelitian yang dilakukan.

\subsection{Waktu dan Tempat Penelitian}

Penelitian ini dilaksanakan pada Kantor Wilayah Kementrian Agama Provinsi Sulawesi Utara yang bertempat di Jl. 17 Agustus, Kota Manado, Sulawesi Utara. Waktu Penelitian dimulai dari Maret sampai dengan bulan April 2018.

\subsection{Prosedur Penelitian}

Mengidentifikasi masalah, menentukan objek penelitian, penyusunan proposal penelitian, pengumpulan data, menganalisis dan mengolah data, hasil penelitian, membuat kesimpulan dan memberikan saran.

\subsection{Metode Analisis}

Sugiyono (2014:3) menyatakan metode penelitian pada dasarnya merupakan cara ilmiah untuk mendapatkan data dengan tujuan dan kegunaan tertentu dan untuk menggambar atau menganalisis suatau hasil penelitian tetapi tidak digunakan untuk membuat kesimpulan yang lebih luas . Metode penelitian yang digunakan dalam penelitian ini adalah metode deskriptif.

\section{HASIL ANALISIS DAN PEMBAHASAN}

4.1. Hasil analisis

4.2.1. Klasifikasi Barang Milik Negara (Aset Tetap) Pada Kantor Wilayah Kementerian Agama Provinsi Sulawesi Utara

Adapun klasifikasi Barang Milik Negara pada Kantor Wilayah Kementerian Agama Provinsi Sulawesi Utara terdiri dari: 
a. Persediaan

Persediaan pada Kantor Wilayah Kementerian Agama Provinsi Sulawesi Utara terdiri dari persediaan alat tulis kantor, alat listrik dan elektronik (lampu pijar dan batrei), materai, peralatan kebersihan dan bahan pembersih serta bahan bakar solar.

b. Peralatan dan mesin

Peralatan dan mesin pada Kantor Wilayah Kementerian Agama Provinsi Sulawesi Utara diklasifikasikan sesuai dengan jenisnya seperti alat perkantoran, komputer/leptop, meja, kursi, printer dan lemari.

c. Gedung dan Bangunan

Pada Kantor Wilayah Kementerian Agama Provinsi harus gedung dan bangunan diklasifikasikan berdasarkan jenisnya, seperti gedung perkantoran, rumah dinas, bangunan tempat ibadah, menara, monumen/bangunan bersejarah, gudang, gedung museum.

\subsubsection{Perlakuan Akuntansi Barang Milik Negara Pada Kantor Wilayah Kementerian} Agama Provinsi Sulawesi Utara

Dalam menjamin akuntabilitas dan transparansi Barang Milik Negara perlu disusun laporan pertaggungjawaban. Dimana akuntansi sebagai bentuk pertaggungjawaban pelaksanaan Barang Milik Negara berperan mencatat pengelolaan Barang Milik Negara yang telah terjadi, menyajikan dan mengungkapkannya dalam laporan keuangan. Pada Kantor Wilayah Kementerian Agama Provinsi Sulawesi Utara. Mengimplementasikan perlakuan akuntansi atas Barang Milik Negara Berbasis Akrual yang terdiri atas Pengakuan, Pengukuran, serta Penyajian dan Pengungkapan dalam laporan keuangan.

Adapun perlakuan akuntansi atas Barang Milik Negara pada Kantor Wilayah Kementerian Agama Provinsi Sulawesi Utara sebagai berikut :

\section{Perlakuan Akuntansi (Persediaan)}

a. Pengakuan

Pengakuan persediaan pada Kantor Wilayah Kementerian Agama Provinsi Sulawesi Utara diakui pada saat potensi manfaat ekonomi masa depan diperoleh pemerintah dan mempunyai nilai atau biaya yang dapat diukur dengan andal.

b. Pengukuran

Pengukuran Persediaan pada Kantor Wilayah Kementerian Agama Provinsi Sulawesi Utara disajikan sebesar biaya perolehan, biaya perolehan yang dimaksud yaitu biaya yang diperoleh dengan pembelian maka, biaya perolehan persediaan meliputi harga pembelian. Apabila dalam pembelian persediaan terdapat potongan harga, rabat (potongan harga non eceran yang diberikan langsung oleh produsen atas pembelian dalam jumlah besar,dan lainnya yang serupa maka akan mengurangi biaya perolehan. Sehingga nilai pembelian yang digunakan adalah biaya perolehan persediaan yang terakhir diperoleh.

c. Penyajian

Penyajian persediaan pada Kantor Wilayah Kementerian Agama Provinsi Sulawesi Utara disajikan di dalam Neraca sebesar nilai moneternya.

d. Pengungkapan

Disamping disajikan di dalam Neraca pengungkapan atas transaksi pembelian persediaan pada Kantor Wilayah Kementerian Agama Provinsi Sulawesi Utara harus diungkapkan sedemikian rupa dalam Catatan atas Laporan Keuangan sehingga dapat memberikan informasi yang relevan mengenai pembelian persediaan.

Jenis informasi atas transaksi pembelian persediaan yang dapat dijelaskan pada Catatan atas Laporan Keuangan pada Kantor Wilayah Kementerian Agama Provinsi Sulawesi Utara, antara lain:

1. Kebijakan akuntansi yang digunakan dalam pengukuran persediaan. 
2. Penjelasan lebih lanjut mengenai persediaan seperti barang atau perlengkapan apa saja yang digunakan dalam keperluan kantor.

3. Kondisi persediaan;

Hal-hal lain yang perlu diungkapkan berkaitan dengan persediaan, misalnya Persediaan dengan kondisi rusak atau usang tidak dilaporkan dalam neraca, tetapi diungkapkan dalam Catatan atas Laporan Keuangan.

\section{Aset Tetap}

1. Peralatan dan mesin

Adapun Perlakuan Akuntansi terhadap aset tetap (peralatan dan mesin pada Kantor Wilayah Kementerian Agama Provinsi Sulawesi Utara sebagai berikut:

a. Pengakuan

Pengakuan peralatan dan mesin pada Kantor Wilayah Kementerian Agama Provinsi Sulawesi Utara diakui apabila terdapat bukti bahwa hak/kepemilikan telah berpindah, dan ditandai dengan berita acara serah terima pekerjaan sedangkan, untuk kendaraan bermotor harus dilengkapi dengan bukti kepemilikan kendaraan. Dimana perolehan peralatan dan mesin pada Kantor Wilayah Kementerian Agama Provinsi Sulawesi Utara melalui pembelian secara tunai. Adapun perolehan peralatan dan mesin melalui pembelian dilakukan dengan pembelian tunai dimana diakui sebagai penambah nilai peralatan dan mesin, dan mengurangi Kas Umum Negara pada neraca dan harus disajikan dalam Laporan Realisasi Anggaran dan diakui sebagai belanja modal.

b. Pengukuran/Penilaian

Pengukuran peralatan dan mesin pada Kantor Wilayah Kementerian Agama Provinsi Sulawesi Utara dinilai dengan biaya perolehan, apabila penilaian peralatan dan mesin menggunakan biaya perolehan tidak memungkinkan maka penilaian peralatan dan mesin pada Kantor Kementerian Agama dinilai pada nilai wajar pada saat perolehan peralatan dan mesin tersebut.

c. Penyajian

Peralatan dan mesin pada Kantor Wilayah Kementerian Agama Provinsi Sulawesi Utara disajikan berdasarkan biaya perolehan peralatan dan mesin yang telah dikurangi dengan akumulasi penyusutan peralatan dan mesin tersebut pada satu periode dan harus disajikan sebagai beban penyusutan dalam Laporan Operasional.

d. Pengungkapan

Disamping disajikan sebagai beban penyusutan dalam Laporan Operasional, pengungkapan atas peralatan dan mesin pada Kantor Wilayah Kementerian Agama Provinsi Sulawesi Utara harus juga diungkapkan sedemikian rupa pada Catatan atas Laporan Keuangan.

Adapun jenis informasi mengenai peralatan dan mesin yang dijelaskan pada Catatan atas Laporan Keuangan, antara lain:

1. Dasar penilaian yang digunakan untuk menentukan nilai yang tercatat (carrying amount) terhadap Peralatan dan Mesin.

2. Kebijakan akuntansi untuk kapitalisasi yang berkaitan dengan Peralatan dan Mesin.

3. Nilai Peralatan dan Mesin yang tercatat dalam rekonsiliasi pada awal dan akhir periode yang menunjukkan:

a. Penambahan pada saat pembelian dan pertukaran peralatan dan mesin tersebut.

b. Perolehan yang berasal dari pembelian yang telah direkonsiliasi dengan total yang benar. 
c. Informasi penyusutan Peralatan dan Mesin yang meliputi: nilai penyusutan, metode penyusutan yang digunakan, serta mengapa alasan memilih metode penyusutan tersebut. Nilai penyusutan yang dimaksud yaitu nilai perolehan peralatan dan mesin pada saat pembelian yang harus dikurangi dengan nilai sisa (reisdu). Metode penyusutan yang digunakan pada Kantor Wilayah Kementerian Agama adalah metode garis lurus. Sedangkan alasan menggunaka metode garis lurus (straight line method) adalah karena metode tersebut lebih efektif dan evisien dalam menentukan berapa nilai penyusutan terhadap peralatan dan mesin tersebut.

2. Gedung dan Bangunan

Adapun Perlakuan Akuntansi terhadap aset tetap (gedung dan bangunan) pada Kantor Wilayah Kementerian Agama Provinsi Sulawesi Utara sebagai berikut:

a. Pengakuan

Pengakuan gedung dan bangunan pada Kantor Wilayah Kementerian Agama Provinsi Sulawesi Utara diakui pada saat gedung dan bangunan telah diterima atau diserahkan hak kepemilikannya dan/atau pada saat penguasaannya berpindah serta telah siap dipakai. Perolehan gedung dan bangunan pada objek penelitian melalui pembelian dan tukar menukar, perolehan gedung dan bangunan melalui pembelian pada Kantor Wilayah Kementerian Agama dilakukan dengan pembelian secara tunai,dimana diakui sebagai penambah nilai gedung dan bagunan,dan mengurangi Kas Umum Negara pada neraca. Disamping itu disajikan dalam laporan realisasi anggaran diakui sebagai belanja modal.

b. Pengukuran/Penilaian

Pengukuran gedung dan bangunan pada Kantor Wilayah Kementerian Agama dinilai dengan biaya perolehan. Biaya perolehan pada kantor tersebut meliputi seluruh biaya yang dikeluarkan untuk memperoleh gedung dan bangunan sampai siap pakai.

c. Penyajian

Penyajian gedung dan bangunan pada Kantor Wilayah Kementerian Agama disajikan berdasarkan biaya perolehan gedung dan bangunan tersebut yang telah dikurangi dengan akumulasi penyusutan. Disamping itu gedung dan bangunan harus juga disajikan didalam neraca. Sedangkan penyusutan atas gedung dan bngunan pada satu periode disajikan sebagai beban penyusutan dalam laporan operasional.

d. Pengungkapan

Disamping disajikan sebagai beban penyusutan dalam Laporan Operasional, pengungkapan atas gedung dan bangunan pada Kantor Wilayah Kementerian Agama Provinsi Sulawesi Utara harus juga diungkapkan sedemikian rupa pada Catatan atas Laporan Keuangan.

Adapun jenis informasi mengenai gedung dan bangunan yang dijelaskan pada Catatan atas Laporan Keuangan, antara lain:

a. Dasar penilaian yang digunakan untuk mencatat gedung dan bangunan.

b. Kebijakan akuntansi untuk kapitalisasi yang berkaitan dengan gedung dan bangunan tersebut.

c. Rekonsiliasi nilai yang tercatat atas gedung dan bangunan tersebut pada awal dan akhir periode yang menunjukan:

a) Penambahan atas pembeliandan pertukaran gedung dan bangunan tersebut.

b) Perolehan yang berasal dari pembelian yang telah direkonsiliasi dengan total belanja modal untuk gedung dan bangunan tersebut. 


\subsubsection{Mekanisme Pelaporan Barang Milik Negara Pada Kantor Wilayah Kementerian Agama Provinsi Sulawesi Utara}

Dalam Kantor Wilayah Kementerian Agama Provinsi Sulawesi Utara, sebelum dilakukan pelaporan Barang Milik Negara ke Kantor Pelayanan Kekayaan Negara dan Lelang,Kantor Wilayah Kementerian Agama melakukan rekoninternal antara operator sub bagian BMN dengan persediaan delapan eselon, setelah rekoninternal anatara operator sub BMN dengan persediaan telah sesuai, maka selanjutnya di input kedalam Sistem Akuntansi Instansi Berbasis Akrual untuk menganalisis laporan keuangan,dimana laporan keuangan yang dimaksud disini adalah neraca,jika dalam laporan keuangan neraca telah sesuai tidak terjadi selisih maka selanjutnya pihak Kantor Kementerian Agama melakuakan rekonsiliasi ke Kantor Pelayanan Kekayaan Negara Dan Lelang, setelah melakukan rekonsiliasi maka akan keluar barang dan dicatat kedalam laporan ekstrakomptabel.

\subsection{Pembahasan}

\subsubsection{Analisis Perlakuan Akuntansi Atas Persedian Barang Milik Negara Pada Kantor} Wilayah Kementerian Agama Provinsi Sulawesi Utara

Berdasarkan penelitian yang dilakukan bahwa perlakuan akuntansi atas persedian pada Kantor Wilayah Kementerian Agama Provinsi Sulawesi Utara berbasis akrual. Adapun perlakuan akuntansi atas persediaan pada Kantor Wilayah Kementerian Agama Provinsi Sulawesi Utara meliputi pengakuan, pengukuran, penyajian dan pengungkapan. Dimana pengakuan persediaan pada Kantor Wilayah Kementerian Agama Provinsi Sulawesi Utara diakui pada saat potensi manfaat ekonomi masa depan diperoleh pemerintah dan mempunyai nilai atau biaya yang dapat diukur dengan andal. Adapun Pengukuran Persediaan disajikan sebesar biaya perolehan, biaya perolehan yang dimaksud yaitu biaya yang diperoleh dengan pembelian, maka biaya perolehan persediaan meliputi harga pembelian. Apabila dalam pembelian persediaan terdapat potongan harga, rabat (potongan harga non eceran yang diberikan langsung oleh produsen atas pembelian dalam jumlah besar), dan lainnya yang serupa maka akan mengurangi biaya perolehan. Sehingga nilai pembelian yang digunakan adalah biaya perolehan persediaan yang terakhir diperoleh.

Penyajian persediaan pada Kantor Wilayah Kementerian Agama Provinsi Sulawesi Utara disajikan di dalam Neraca sebesar nilai moneternya. Disamping disajikan di dalam Neraca pengungkapan atas transaksi pembelian persediaan pada Kantor Wilayah Kementerian Agama Provinsi Sulawesi Utara harus diungkapkan sedemikian rupa dalam Catatan atas Laporan Keuangan sehingga dapat memberikan informasi yang relevan mengenai pembelian persediaan. Adapun pencatatan perlakuan akuntansi atas pembelian persedian pada Kantor Wilayah Kementerian Agama Provinsi Sulawesi Utara adalah sebagai berikut:

Tabel 4.1

Kantor Wilayah Kementerian Agama Provinsi Sulawesi Utara Jurnal Pembelian Persediaan

\begin{tabular}{|c|c|c|}
\hline Nama Akun & Debet & Kredit \\
\hline Persediaan alat kantor & $\mathrm{xxx}$ & - \\
\hline Kas dibendahara pengeluaran & - & $\mathrm{xxx}$ \\
\hline Belanja alat tulis kantor & $\mathrm{xxx}$ & - \\
\hline Perubahan SAL & - & $\mathrm{xxx}$ \\
\hline
\end{tabular}


Dari tabel 4.1 menunjukkan bahwa penjurnalan dilakukan 2 kali yang pertama yaitu, persediaan alat kantor berada pada sisi debet, sedangkan kas dibendahara pengeluaran berada pada sisi kredit dimana itu untuk pencatatan dalam LO. Untuk penjurnalan yang kedua menunjukkan bahwa belanja alat tulis kantor berada pada sisi debet sedangkan perubahan SAL berada pada sisi kredit dimana itu untuk pencatatan dalam LRA.

\subsubsection{Analisis Perlakuan Akuntansi Barang Milik Negara Atas Peralatan dan Mesin \\ Pada Kantor Wilayah Kementerian Agama Provinsi Sulawesi Utara}

Berdasarkan penelitian yang dilakukan bahwa perlakuan akuntansi atas peralatan dan mesin pada Kantor Wilayah Kementerian Agama Provinsi Sulawesi Utara menggunakan Standar Akuntansi Pemerintah Berbasis Akrual dimana dalam pelaporan finansial mengakui pendapatan beban, asset, utang dan ekuitas, dan dalam pelaksanaan anggaran mengakui pendapatan, belanja dan pembiayaan berdasarkan basis yang ditetapkan dalam APBN/APBD. Perlakuan akuntansi asset tetap berbasis akrual dituangkan dalam Standar Akuntansi Pemerintah BULTEK Nomor 15 tentang asset tetap. Adapun perlakuan akuntansi Barang Milik Negara atas peralatan dan mesin pada Kantor Wilayah Kementerian Agama Provinsi Sulawesi Utara dimana pengakuan peralatan dan mesin diakui apabila memiliki bukti bahwa hak/kepemilikan telah dialihkan, dan harus disertai dengan berita acara serah terima pekerjaan, sedangkan untuk kendaraan bermotor harus dilengkapi dengan bukti kepemilikan kendaraan. Dimana perolehan peralatan dan mesin pada Kantor Wilayah Kementerian Agama Provinsi Sulawesi Utara melalui pembelian secara tunai. Adapun perolehan peralatan dan mesin melalui pembelian yang dilakukan secara tunai diakui sebagai penambah nilai peralatan dan mesin, dan mengurangi Kas Umum Negara pada neraca dan harus disajikan dalam Laporan Realisasi Anggaran dan diakui sebagai belanja modal. Sedangkan pengukuran peralatan dan mesin pada Kantor Wilayah Kementerian Agama Provinsi Sulawesi Utara dinilai dengan biaya perolehan, apabila penilaian peralatan dan mesin menggunakan biaya perolehan tidak memungkinkan, maka penilaian peralatan dan mesin pada Kantor Wilayah Kementerian Agama dinilai sebagai nilai wajar pada saat perolehan peralatan dan mesin tersebut.

Peralatan dan mesin pada Kantor Wilayah Kementerian Agama Provinsi Sulawesi Utara disajikan berdasarkan biaya perolehan peralatan dan mesin yang telah dikurangi dengan akumulasi penyusutan peralatan dan mesin tersebut pada satu periode dan harus disajikan sebagai beban penyusutan dalam Laporan Operasional. Disamping disajikan sebagai beban penyusutan dalam Laporan Operasional, pengungkapan atas peralatan dan mesin pada Kantor Wilayah Kementerian Agama Provinsi Sulawesi Utara harus juga diungkapkan sedemikian rupa pada Catatan atas Laporan Keuangan. Adapun pencatatan perlakuan akuntansi atas pembelian peralatan dan mesin pada Kantor Wilayah Kementerian Agama Provinsi Sulawesi Utara adalah sebagai berikut:

Tabel 4.2

Kantor Wilayah Kementerian Agama Provinsi Sulawesi Utara Jurnal Pembelian Peralatan dan Mesin

\begin{tabular}{|c|c|c|}
\hline Nama Akun & Debet & Kredit \\
\hline Aset Tetap - Peralatan dan Mesin & $\mathrm{xxx}$ & - \\
\hline Kas di Kas Umum Negara & - & $\mathrm{xxx}$ \\
\hline Belanja Modal Peralatan dan Mesin & $\mathrm{xxx}$ & - \\
\hline Perubahan SAL & - & $\mathrm{xxx}$ \\
\hline
\end{tabular}


Dari tabel 4.2 menunjukkan bahwa penjurnalan dilakukan 2 kali yang pertama yaitu, Aset Tetap - Peralatan dan Mesin berada pada sisi debet, sedangkan Kas di Kas Umum Negara sisi kredit dimana itu untuk pencatatan dalam LO . Untuk penjurnalan yang kedua menunjukkan bahwa belanja modal peralatan dan mesin berada pada sisi debet sedangkan perubahan SAL berada pada sisi kredit dimana itu untuk pencatatan dalam LRA.

Tabel 4.3

Kantor Wilayah Kementerian Agama Provinsi Sulawesi Utara Jurnal Penghentian dan Pelepasan Aset

\begin{tabular}{|c|c|c|}
\hline Nama Akun & Debet & Kredit \\
\hline Akumulasi Penyusutan Aset tetap & $\mathrm{xxx}$ & - \\
\hline Defisit Penghentian Aset Lainnya & $\mathrm{xxx}$ & - \\
\hline Aset Tetap & - & $\mathrm{xxx}$ \\
\hline
\end{tabular}

Dari tabel 4.3 menunjukkan bahwa akumulasi penyusutan aset tetap dan defisit penghentian asset lainnya berada pada sisi debet, sedangkan aset tetap pada sisi kredit.

4.2.3. Analisis Perlakuan Akuntansi Barang Milik Negara Atas Gedung dan Bangunan Pada Kantor Wilayah Kementerian Agama Provinsi Sulawesi Utara

Berdasarkan penelitian yang dilakukan bahwa perlakuan Akuntansi atas gedung dan bangunan pada Kantor Wilayah Kementerian Agama Provinsi Sulawesi Utara menggunakan Standar Akuntansi Pemerintah Berbasis Akrual dimana dalam pelaporan finansial mengakui pendapatan beban, asset, utang dan ekuitas dan dalam pelaksanaan anggaran mengakui pendapatan, belanja dan pembiayaan berdasarkan basis yang ditetapkan dalam APBN/APBD. Perlakuan akuntansi berbasis akrual tentang perlakuan akuntansi asset tetap berbasis akrual dituangkan dalam Standar Akuntansi Pemerintah BULTEK Nomor 15 tentang asset tetap. Adapun perlakuan akuntansi Barang Milik Negara atas gedung dan bangunan pada Kantor Wilayah Kementerian Agama Provinsi Sulawesi Utara dimana pengakuan gedung dan bangunan pada Kantor Wilayah Kementerian Agama Provinsi Sulawesi Utara diakui pada saat diterima atau diserahkan hak kepemilikannya dan/atau pada saat penguasaannya berpindah serta telah siap dipakai. Perolehan gedung dan bangunan pada objek penelitian melalui pembelian dan tukar menukar, perolehan gedung dan bangunan melalui pembelian pada Kantor Wilayah Kementerian Agama dilakukan dengan pembelian secara tunai,dimana diakui sebagai penambah nilai gedung dan bagunan,dan mengurangi Kas Umum Negara pada neraca.

Disamping itu disajikan dalam Laporan Realisasi Anggaran diakui sebagai belanja modal. Sedangkan untuk pengukuran gedung dan bangunan pada Kantor Wilayah Kementerian Agama dinilai dengan biaya perolehan. Biaya perolehan pada kantor tersebut meliputi seluruh biaya yang dikeluarkan untuk memperoleh gedung dan bangunan sampai siap pakai. Penyajian gedung dan bangunan pada Kantor Wilayah Kementerian Agama disajikan berdasarkan biaya perolehan gedung dan bangunan tersebut yang telah dikurangi dengan akumulasi penyusutan. Disamping itu gedung dan bangunan harus juga disajikan didalam neraca. Sedangkan penyusutan atas gedung dan bangunan pada satu periode disajikan sebagai beban penyusutan dalam Laporan Operasional. Selain disajikan sebagai beban penyusutan dalam Laporan Operasional, pengungkapan atas gedung dan bangunan pada Kantor Wilayah Kementerian Agama Provinsi Sulawesi Utara harus juga diungkapkan sedemikian rupa pada Catatan atas Laporan Keuangan. Adapun pencatatan perlakuan akuntansi atas pembelian gedung dan bangunan pada Kantor Wilayah Kementerian Agama Provinsi Sulawesi Utara adalah sebagai berikut: 
Tabel 4.4

Kantor Wilayah Kementerian Agama Provinsi Sulawesi Utara Jurnal Pembelian Bangunan Gedung Kantor

\begin{tabular}{|c|c|c|}
\hline Nama Akun & Debet & Kredit \\
\hline Bangunan Gedung Kantor & $\mathrm{xxx}$ & - \\
\hline Bendahara Umum Negara & - & $\mathrm{xxx}$ \\
\hline Belanja Modal Pengadaan Bangunan Gedung Kantor & $\mathrm{xxx}$ & - \\
\hline Perubahan SAL & - & $\mathrm{xxx}$ \\
\hline
\end{tabular}

Dari tabel 4.4 menunjukkan bahwa penjurnalan dilakukan 2 kali yang pertama yaitu, bangunan gedung kantor berada pada sisi debet, sedangkan bendahara umum negara sisi kredit, dimana itu untuk pencatatan dalam LO. Untuk penjurnalan yang kedua menunjukkan bahwa belanja modal pengadaan bangunan gedung kantor berada pada sisi debet sedangkan perubahan SAL berada pada sisi kredit dimana itu untuk pencatatan dalam LRA.

Tabel 4.5

Kantor Wilayah Kementerian Agama Provinsi Sulawesi Utara Jurnal Penghentian dan Pelepasan Aset

\begin{tabular}{|c|c|c|}
\hline Nama Akun & Debet & Kredit \\
\hline Akumulasi Penyusutan Aset tetap & $\mathrm{xxx}$ & - \\
\hline Defisit Penghentian Aset Lainnya & $\mathrm{xxx}$ & - \\
\hline Aset Tetap & - & $\mathrm{xxx}$ \\
\hline
\end{tabular}

Dari tabel 4.5 menunjukkan bahwa akumulasi penyusutan aset tetap dan defisit penghentian asset lainnya berada pada sisi debet, sedangkan aset tetap pada sisi kredit.

4.2.4. Analisis Pelaporan Barang Milik Negara pada Kantor Wilayah Kementerian Agama Provinsi Sulawesi Utara

Berdasarkan penelitian yang dilakukan bahwa pelaporan barang milik negara pada Kantor Wilayah Kementerian Agama Provinsi Sulawesi Utara mengacu pada Buletin Teknis (BULTEK) Nomor 15 Tentang Aset Tetap. Dimana dalam Buletin Teknis mengatur akuntansi dan pelaporan Lembaga/Kementerian untuk asset tetap Barang Milik Negara pada Pemerintah Pusat dan Daerah. Didalam Bultek ini pelaporan Barang Milik Negara dilaporkan secara tepat waktu, transparan, dan akurat sehingga hasilnya dapat dipertanggungjawabkan sesuai ketentuan perundang-undangan. Adapun mekanisme pelaporan Barang Milik Negara di Kantor Wilayah Kementerian Agama yaitu pertama melakukan rekoninternal antara operator sub bagian BMN dengan persediaan delapan eselon, setelah rekoninternal antara operator sub BMN dengan persediaan telah sesuai, maka selanjutnya di input kedalam Sistem Akuntansi Instansi Berbasis Akrual untuk menganalisis laporan keuangan,dimana laporan keuangan yang dimaksud disini adalah neraca, jika dalam laporan keuangan neraca telah sesuai tidak terjadi selisih maka selanjutnya pihak Kantor Kementerian Agama melakuakan rekonsiliasi ke Kantor Pelayanan Kekayaan Negara Dan Lelang, setelah melakukan rekonsiliasi maka akan keluar barang dan dicatat kedalam laporan ekstrakomptabel.

Jadi pelaporan BMN pada Kantor Wilayah Kementerian Agama Provinsi Sulawesi Utara sudah sesuai dengan prosedur sebagaimana yang telah diatur pada Standar Akuntansi Pemerintahan Buletin Teknis nomor 15 dimana pelaporannya harus dilaporkan secara tepat waktu dan akurat. Walaupun Kantor Wilayah Kementerian Agama Provinsi Sulawesi Utara prosedur pelaporannya sudah sesuai dengan Standar Akuntansi Pemerintahan nomor 15 tetapi masih saja mengalami kendala dalam pelaporan. Adapun kendala dalam pelaporan tersebut yaitu terjadinya keterlambatan dari tiap-tiap bidang dalam membuat persediaan, belanja modal peralatan dan mesin, dimana dari masing-masing bidang harus mengimputnya ke 
BMN diakibatkan karena kurangnya sumber daya manusia (SDM). Berdasarkan kendalakendala tersebut, maka hal ini juga berdampak pada pelaporan dari pihak Kantor Wilayah Kementerian Agama Provinsi Sulawesi Utara (selaku kuasa pengguna anggaran) dimana pada saat pemasukan laporan mengenai data BMN yang akan direkonsiliasi pada KPKNL (Kantor Pelayanan Kekayaan Negara dan Lelang) sesuai jadwal yang telah ditentukan akantetapi pihak Kantor Kementerian Aagama belum bisa memepertanggungjawabkan laporan mengenai data BMN.

\section{KESIMPULAN DAN SARAN}

\subsection{Kesimpulan}

Berdasarkan hasil penelitian yang didapat maka penulis mengambil kesimpulan bahwa perlakuan akuntansi Barang Milik Negara Pada Kantor Wilayah Kementerian Agama Provinsi Sulawesi Utara telah sesuai dengan Standar Akuntansi Pemerintahan Buletin Teknis nomor 15. Dimana dalam Standar Akuntansi Pemerintahan yang di atur dalam Buletin Teknis nomor 15 menyatakan bahwa perlakuan akuntansi terhadap barang milik negara harus berbasis akrual. Adapun mekanisme pelaporan barang milik negara pada Kantor Wilayah Kementerian Agama Provinsi Sulawesi Utara juga telah sesuai dengan Standar Akuntansi Pemerintahan Buletin Teknis nomor 15. Dimana Kantor Wilayah Kementerian Agama Provinsi Sulawesi Utara dalam pelaporannya dilakukan secara tepat waktu, transparan dan akurat sehingga hasilnya dapat dipertanggungjawabkan, walaupun pelaporan barang milik negara pada Kantor Wilayah Kementerian Agama Provinsi Sulawesi Utara sudah sesuai dengan Standar Akuntansi Pemerintahan Buletin Teknis 15 namun terdapat kendala pada saat pelaporan dikarenakan keterlambatan dari tiap-tiap bidang yang belum membuat persediaan, belanja modal peralatan dan mesin yang seharusnya diinput langsung ke Barang Milik Negara. Adapun sumber daya manusia yang tidak memadai pada Kantor Wilayah Kementerian Agama Provinsi Sulawesi Utara sehingga memeperlambat penginputan data dari tiap-tiap eselon. Oleh karena itu, Kantor Wilayah Kementerian Agama Provinsi Sulawesi Utara belum bisa mempertanggungjawabkan beberapa bukti laporan Barang Milik Negara tersebut kepada pihak Kantor Pelayanan Kekayaan Negara dan Lelang pada saat pemeriksaan

sehingga Kantor Wilayah Kementerian Agama tidak tepat waktu dalam mempertanggungjawabkan pelaporannya.

\subsection{Saran}

Berdasarkan analisa data yang telah dibahas sebelumnya, maka penulis memberikan saran antara lain:

1. Diharapkan Kantor Wilayah Kementerian Agama Provinsi Sulawesi Utara selalu berpedoman pada Standar Akuntansi Pemerintahan Buletin Teknis nomor 15 tentang aset tetap Barang Milik Negara berbasis akrual, sehingga perlakuan akuntansi terhadap Barang Milik Negara tetap berjalan dengan baik.

2. Kantor Wilayah Kementerian Agama Provinsi Sulawesi Utara harus tetap mengacu pada Standar Akuntansi Pemerintahan Buletin Teknis nomor 15 sehingga mekanisme pelaporan Barang Milik Negara tetap dapat dipertanggungjawabkan.

3. Diadakannya penambahan Sumbaer Daya Manusia (SDM) pada Kantor Wilayah Kementerian Agama Provinsi Sulawesi Utara lebih khususnya dalam mengelola data Barang Milik Negara, sehingga kedepannya tidak terjadi keterlambatan dalam pelaporan Barang Milik Negara ke pihak KPKNL. 


\section{DAFTAR PUSTAKA}

Azwar, Limrah. 2015. Analisis System Informasi Akuntansi atas Manajement Asset Tetap Barang Milik Negara (studi kasus pada satuan kerja kantor pelayanan kekayaan negara dan lelang KPKNL malang). Skripsi. Universitas Muhammadiyah. Malang.

Afrida, M. Timala. 2012. Analisis Kegiatan Pengendalian pada Proses Penatausahaan Barang Milik Negara (BMN) pada Secretariat Jendral Kementerian P erdagangan. Skripsi. Universitas Indonesia. Jakarta.

Anggraeni., dan Ayang, P. Septiayu. 2015. Pengaruh Penatausahaan Barang Milik Negara (BMN) terhadap Kualitas Laporan Keuangan pada Kantor Kementerian Agama Kota Probolinggo. Skripsi. Universitas Islam Negeri Maulana Malik Ibrahim. Malang.

Bastian, Indra. 2010. Akuntansi Sektor Publik Suatu Pengantar. Edisi Ketiga. Erlangga. Jakarta.

Chabib Sholeh dan Heru Rochmansjah,2010, Pengelolaan Keuangan dan Aset Daerah Sebuah Pendekatan Struktural Menuju Tata Kelola Pemerintahan Yang Baik.Bandun: Fokusmedia.

Pawit, M, Yusuf. 2010. Komunikasi Instruksional:teori dan praktek. Jakarta: PT. Bumi Aksara.

Peraturan Menteri Keuangan Nomor 96/PMK.06/2007. tentang Tata Cara Pelaksanaan, Penggunaan Dan Pemanfaatan Penghapusan Dan Pemindahtanganan Barang Milik Negara.

Peraturan Pemerintah Nomor 71 Tahun 2010. Standar Akuntansi Pemerintahan. Lembaran Negara Republik Indonesia Tahun 2010 Nomor 47. Jakarta.

.Nomor 1 Tahun 2004. Perbendaharaan Negara. Lembaran Negara Republik Indonesia Tahun 2004. Jakarta.

Riskie, S. Safitri. 2015. Analisis perlakuan akuntansi aset tetap berdasarkan PSAP no 07 (studi kasus pada Dinas Pertanian dan Ketahanan Pangan Provinsi Jawa Timur. Skripsi. Sekolah Tinggi ilmu ekonomi Indonesia (SETIESIA). Surabaya.

Siagian, P. Sondang. 2011. Manajemen Sumber Daya Manusia. PT. BumiAksara. Jakarta. Sugiyono. 2014. Metode Penelitian Kuantitatif, Kualitatif dan R\&D. Alfabeta. Bandung. Sukmadinata. 2013. Metode Penelitian Pendidikan. PT Remaja Rosda karya. Bandung. 